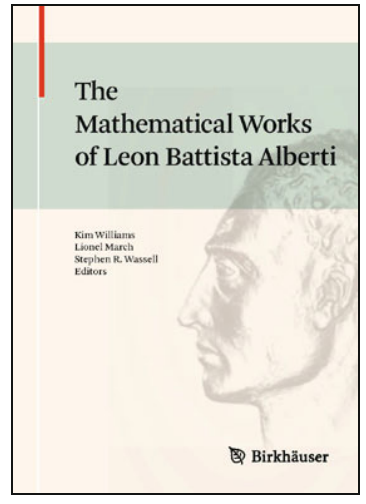

Keywords: Leon Battista Alberti, Ludi matematici, cipher codes, measuring, history of mathematics
Book Review

\section{Kim Williams, Stephen R. Wassell, Lionel March (eds.) \\ The Mathematical Works of Leon Battista Alberti}

Basel: Birkhäuser, 2010

Reviewed by Sylvie Duvernoy

Via Benozzo Gozzoli, 26

50124 Florence ITALY

syld@kimwilliamsbooks.com

Leon Battista Aberti spent thirty-two years in the Papal Court, earning his living with his pen. Besides being an "Abbreviator" at the Vatican, he was a prolific writer; his first personal success was a comedy, Philodoxeos, which he wrote at the age of twenty. His multifaceted interests led him to study different scientific disciplines and consequently the corpus of his literary production covers a wide range of topics.

The present book is dedicated to his mathematical works, and gathers four writings which all are related to mathematics; three of them also deal with another discipline. The first text, Ex ludis rerum mathematicarum (more often cited as Ludi matematici), is related to problems of survey and measurements; the second, Elementi di pittura (Elements of Painting, not to be confused with the more famous De pictura), is related to painting; the third, De componendis cifris (On Writing in Ciphers), is related to cryptology; the last, De lunularum quadratura (On Squaring the Lune), is the only text to deal with pure theoretical mathematics. The book proposes the transcription of a manuscript of Ludi matematici held in the Biblioteca Nazionale in Florence (ms. no. Galileana 10), together with a fresh translation and a commentary for each of the four texts.

The three authors of the volume are scholars in mathematics and architecture, certainly well-known to the readership of the Nexus Network Journal (of which Kim Williams is editor-in-chief), who have long inquired into the historical relationship between both disciplines. Prof. Stephen Wassell (mathematician) and Kim Williams (architect) have already published the translation of the short Renaissance treatise by Silvio Belli, On Ratio and Proportion [Belli 2003], for which Lionel March wrote a foreword. Prof. Lionel March (architect) has also written a number of important books, among which Architectonics of Humanism: Essays on Number in Architecture [1998] which testify to his profound knowledge in both architecture and mathematics.

Of the four mathematical writings by Alberti published here, the most important one is indeed the first, Ludi matematici.

Any scholar in art history and architecture history is familiar with the major writings of Leon Battista Alberti dealing with the fine arts, which comprise the famous treatise De 
re aedificatoria and the book whose Latin title is De pictura. Both books have long been translated in English and a number of other languages. In fact the problem with which the non-Italian reading Alberti scholars are faced with, when they want to refer to his work, is: which translation to choose in order to get the most of the original text? The most recent English edition of the De re aedificatoria is the translation by Joseph Rykwert, Neil Leach and Robert Tavernor [1988; see also Tavernor 1998]. Tavernor is the author of the preface of this present work. Any serious architecture school library owns at least two or three different editions of both the De re aedificatoria and the De pictura. On the other hand, the booklet whose title is commonly shortened in Ludi matematici (literally, mathematical games or amusements) is more difficult to find. The problem is: which library should own a copy? Should it be the architecture library because the book deals with some basic historical problems of measured surveys, and because anyway Alberti was the architect of the powerful Rucellai family in Florence? Or should it be the math library because the book deals with history of applied mathematics? In Florence, the city in whose National Library the original manuscript (Galileana 10) freshly transcribed here is kept, the famous writings by Alberti are present in the various colleges' libraries, but students can only find a single copy of the Ludi matematici at the philosophy department of the College of Humanities. Until now, the text has always been part of a collection of writings in vulgar and has therefore been catalogued by editors - and librarians - not for its content but for its form, considering the language in which it was written: not Latin but Italian.

It seems therefore that the Ludi matematici has so far been much less well-known than the other writings by Alberti. In fact this edition offers the very first translation in English of the Ludi (more than 550 years after the manuscript's first completion) and hopefully this will make them more accessible and more desirable among scholars and students. In the introduction of Williams, March and Wassell's volume we can read:

\section{Both Ludi Matematici and Elements of Painting have received a} substantial amount of attention in other languages, most notably Italian and French, but they have not in English (p. 1).

The commentary by Stephen Wassell enhances the importance of this somewhat underestimated text, which testifies to the cultural continuity and transmission of knowledge between Antiquity, the Middle Ages and the Renaissance. The text by Alberti, who is both a late Medieval and an early Renaissance man, may provide some clues for the scholars interested in studying the relationship between science and art in the fifteenth century. Alberti does not claim to have invented any kind of measuring system or any new measuring device: he is only transmitting the "playful" - and utmost convenient - mathematical tricks that are useful for solving many problems related to measurements: distances, heights, widths, depths, weights, time, speed, etc., some of which were already present in the sketchbook by the French Villard de Honnecourt some two hundred years before. Alberti is a contemporary of the German Mathes Roriczer whose booklet of 1486 [1977] is well known to scholars, and the comparison between the two texts dating back to the same years points out the importance of Alberti's Ludi.

The second text, Elements of Painting, is not really a literary text, but rather an outline, consisting in lists of drawing exercises that painters must be able to solve, but Alberti does not show solutions nor explains the procedures to solve them. The text is interesting, however, since it testifies to the mathematical/architectural research in Alberti's day, which was dominated by the progresses in perspective drawing. Stephen 
Wassell's commentary focuses on the relationship between three texts: Elements of Painting, On Painting (Alberti's better known book) and Euclid's Elements. It would indeed be interesting to compare this text also to Piero della Francesca's De prospectiva pingendi and to inquire if any exercise is visibly solved in any of the three famous representations of ideal cities that are kept respectively in Urbino, Berlin and Baltimore.

The third text, On Writing in Ciphers, is more delightful to read. In this text Alberti unveils part of his professional experience as an Abbreviator at the Vatican, letting us envision the problems of written communication and secrecy in the diplomatic circles. Alberti was asked by a colleague and friend to figure out a formula for coded writing, and so he did. In his commentary to this text Lionel March states that Alberti made use of his skills in coded language while designing the façade of Santa Maria Novella in Florence. Especially, through the use of precise numbers, March says that Alberti was able to hide his signature in the two scrolls screening the aisles roofs. Is this interpretation going to raise some controversy? Where is the limit between science and esoterism? When speaking of medieval or late medieval art and architecture, this limit is always hard to draw. If we agree with March's interpretation, then we must understand the façade as the design of a late medieval philosopher more than that of a Renaissance humanist.

On the contrary, the last text, the very short On squaring the lune bears witness to the rebirth of theoretical scientific research. The re-reading of both Euclid's Elements and the works by the major ancient mathematicians inspired the Renaissance scientists, who tried to give personal solutions to the three great problems of classical mathematics. Here Alberti is recalling the studies by Hippocrates of Chios on the squaring of the lune. His enthusiasm leads him to conclude that even the circle can be squared. This is a mistake that Alberti and Leonardo da Vinci have in common, as we can see in the sketches collected in the Codex Atlanticus (fol. 455r.).

By putting together these different texts, the volume by Williams March and Wassell presents several peculiar aspects of Alberti's character. Being an innovative thematic collection, this series of writings is in itself interesting and useful to many scholars. Further, it offers an original, pioneering translation, which alone makes the book unique. And, on top of that, the commentaries help to appreciate fully both the content and the significance of each text, in relation to the historical period in which it was written.

\section{References}

AlberTI, Leon Battista. 1988. On the Art of Building in Ten Books. Joseph Rykwert, Neil Leach and Robert Tavernor, trans. Cambridge MA: The MIT Press.

BELLI, Silvio. 2003. On ratio and proportion, Stephen Wassell and Kim Williams, translation and commentary. Fucecchio (Florence): Kim Williams Books (1st ed., 2002).

MARCH, Lionel. 1998. Architectonics of Humanism: Essays on Number in Architecture. London: Academy Editions.

Roriczer Mathes. 1977. Booklet Concerning Pinnacle Correctitude (Büchlein von der Fialen Gerechtigkeit, 1486). Lon Shelby, trans. In Gothic Design Techniques: The FifteenthCentury Design Booklets by Mathes Roriczer and Hanns Schmuttermayer. Carbondale and Edwardsville: Southern Illinois University Press.

TaVernOR, Robert. 1998. On Alberti and the Art of Building. New Haven: Yale University Press.

\section{About the reviewer}

Sylvie Duvernoy is Book Review Editor of the Nexus Network Journal. 